\title{
HUMANISING HIGHER EDUCATION THROUGH A CULTURALLY RESPONSIVE CURRICULUM
}

\author{
K. J. Maluleka \\ Department of Educational Foundations \\ University of South Africa \\ Pretoria, South Africa \\ e-mail: Malulkj1@unisa.ac.za / https://orcid.org/0000-0002-7188-446X
}

\section{ABSTRACT}

During the student protests in South Africa, students indicated that they were still taught irrelevant knowledge after 25 years of independence. The decolonisation of the curriculum was one of the demands of the Fees-Must-Fall protests. The purpose of this chapter is to join the debate by determining the way in which the higher education curriculum can be humanised by making it culturally responsive. This was a qualitative study and the sample included six academics selected from the programme of the London International Conference on Education (LICE-2018) and World Congress on Special Needs Education held from 10 to 13 December 2018 at Cambridge, UK. Presenters whose papers were related to the contextualisation of the curriculum were targeted. An e-mail requesting a 60-minute interview was sent to ten of them. Only five agreed to participate. The participants cited initiatives by Tanzanians (Ujamaa) and Zimbabweans (unhu) to promote culturally responsive education. This study makes recommendations that include education that encourages self-reliance.

Keywords: ujamaa, ubuntu, unhu, curriculum, culturally responsive curriculum, decolonisation, Afrocentric philosophy, curriculum process, curriculum development

\section{INTRODUCTION}

To demonstrate how education was dehumanised in previously colonised countries, I want to start with the following quotation:

\footnotetext{
"My educational experience was marked by a deep sense of isolation that resulted from systematic practices in the U.S. educational system that suppressed vital elements of my humanity, both at home and at school. My experience is not unique; students of colour have been compelled for generations to divest themselves of their linguistic, cultural, and familial resources to succeed in U.S. public schools" (Salazar 2013, 121).
}

This quotation indicates that during the years of colonisation indigenous people felt isolated from their own educational systems. This was because colonisers, wittingly or unwittingly, suppressed vibrant elements of the indigenous people's humanity. The experience of the indigenous people of South Africa is not unique since all colonised people were stripped of 
their linguistic, cultural and ancestral roots.

While indigenous academics, scholars and writers such as Wa Thiong'o (1986, 4), Ndlovu-Gatsheni (2015), Msila (2009), and Msila and Gumbo (2016) suggested ways in which the curriculum can be decolonised, protesting students in South Africa demanded the humanisation of educational content. They indicated that, even after 25 years of independence, they were still being taught irrelevant knowledge. The Fees-Must-Fall protests indicated the need for the decolonisation of the higher education curriculum.

I am convinced that the curricula of higher education must be humanised by making it culturally responsive. Often this involves activities or creations that accommodate the needs of people, like the humanisation of science and technology as advocated by Gale (2005). To achieve the purpose of this study, the question "How can higher education curricula be humanised by making it culturally responsive?" served as a guiding principle.

\section{THEORETICAL FRAMEWORK}

Social constructivism emphasises the collaborative nature of learning and represents a departure (attributed to Vygotsky) from other cognitivist theories championed by theorists such as Piaget and Perry who disconnected learning from the social context. Vygotsky emphasises that learning is a process by which learners integrate with a knowledge community. Therefore, language and culture play a significant role in learning. Similarly, Williams points out that "knowledge is socially created, not individually discovered, and it is created through a process that involves emotion as well as reason" (Kim 2001).

Vygotsky adds another angle to constructivist view. Though he is a cognitivist, does not admit Piaget's and Perry's view that learning can be separated from the social context of learners. He trusts that people learn by networking with others. His theory stresses the responsibility knowledgeable adults have on the learning of children and the development of their thinking skills. His social constructivist theory maintains that human development is socially situated, and knowledge is built through contact with others. It emphasises the collaborative nature of teaching and learning (Galloway 2001). Vygotsky argues that all cognitive meanings are from the social interaction and must therefore be explained as products of social interaction. Therefore, learning is not simply the assimilation and accommodation of new knowledge by students; it is the process by which learners are integrated into a knowledge community. Vygotsky $(1978,57)$ submits that every function in the child's cultural development takes place in two ways: the social level between people (inter-psychologically) and on the individual level inside the learner (intra-psychologically). All cultural development takes place as result of relationships between individuals. 
The next section deals with the literature review.

\section{LITERATURE REVIEW}

This study examines the way in which higher education can agree with the culture of the people taught. Recent calls for a decolonised curriculum by movements such as Fees-Must-Fall demanded a curriculum that is relevant to indigenous people. More specifically, they call for a global vision of a decolonised curriculum. The decolonisation of education is nothing new since leaders such as Julius Nyerere, have attempted to indigenise the education system of Tanzania. Lessons could be learnt from their efforts. For this reason, this study would like to advance African philosophies that will make higher education better suited to indigenous culture. The next section will explain Freire's philosophy of humanisation and some African philosophies by the academics mentioned above.

\section{FREIRE'S PHILOSOPHY OF HUMANISATION}

Paulo Freire, in his work Pedagogy of the Oppressed wrote passionately about what it means to be human. In fact, his critique of oppression and ideas about education were informed by how he approached the problem of being human (Anderson 2016).

Freire, a fundamental democratic humanist, believed that the system of education ought to be in accordance with human rights and the dignity of the people it is supposed to serve (Petrović, Cvetković and Jovanović 2012,35). Humanisation is a significant part of Freire's philosophy (Roberts 2016, 122). He further maintains that it is the way of becoming more fully human as a social, thinking, communicating and creative human being who takes part in the world (Roberts 2016). Huminisation demands that a person be aware of their mission in the world in order to individually and collectively fulfil their social responsibility in the world (Roberts 2016). It is the exercise of liberation in which the oppressed are freed through awareness of their lost position and the desire for autonomy.

As indicated previously, Vygotsky's theory of social constructivism maintains that the practice of humanising does not take place in isolation, but in relationship with other others. It unfolds in a social context characterised by policies, beliefs, values and practices (Roberts 2016). The social context reveals itself in the school context, which explains why social and school problems are connected. Schools educate children. If learners feel discontented, it means that the school fails in its objective to produce people who can develop not only their own personality but also their ability to live with people who are different from themselves (Petrović et al. 2012, 35). One cannot write about schools as a social environment without saying something about education. After all, schools are all about education. 
Education is seen as an important part of what it means to be human. Education is a process of ongoing transformation. Freire advocated education for children and adults from underprivileged and marginalised groups. These are people who are deprived of education since they are not well to do families. Freire was against segregation in education and believed that there should not be privileged people in the process of education. Education should be available to everybody (Petrović et al. 2012, 35). From Freire's viewpoint, an educational system is one of the main instruments of maintaining a culture of silence. Freire tried to show that it is possible to liberate people from silence culture and the trap of ignorance through education and awareness (Mahmoudi, Khoshnood and Babaei 2014, 87).

In addition, Freire emphasised the importance and shortcomings of the current educational policy. He had an entirely different understanding of educational policy and assessed its value through a critical revision of the relations between the participants in school processes (Petrović et al. 2012, 35). Gadotti $(2017,18)$ maintains that Freirean teaching continues to be an important factor in the creation of a fair, democratic globally. Freire insisted on collaborative and engaging procedures; mutually respectful ways of learning and teaching; critical methods of teaching and research; personal relationships; and meaningful dialogue. For Freire, democracy is essential as an approach to overcome social inequalities both inside and outside the learning environment (Gadotti 2017, 18).

\section{A culturally responsive higher education curriculum}

Both social constructivism and the philosophy of humanisation are concerned with the culture of a society. Culture is a complex human phenomenon and a misunderstood concept. It contains both concrete and abstract components (Ford and Moore 2004, 34). Lemmer and Van Wyk $(2012,20)$ argue that the term culture is often used when society is meant. When people refer to African culture, they refer to African society and culture. Spencer-Oatey (2012) considers culture as a set of traditions, values and norms shared by a group of people or community. It embraces knowledge, beliefs, morals, custom and any other capabilities and habits learnt by people as part of society. Ford and Moore $(2004,35)$ argue that culture refers to "a diverse pool of knowledge, shared realities, and clustered norms that constitutes the learned systems of meanings in a particular society". Traditions include myths, folklores, ceremonies and rituals (e.g. celebrating holidays in certain ways) that are passed on either verbally or non-verbally from one generation to another (Ford and Moore 2004, 35). Cultural values refer to a set of priorities that guides notions such as good and bad, fair and unfair, right and wrong. Cultural norms refer to the collective expectations of proper or improper behaviour in a given situation. Norms guide the scripts that groups follow in a particular situation (Ford and Moore 2004, 35). 
All what is mentioned above were shared through daily interaction between members of the cultural group. Culture is a collection of information that is not transmitted between individuals through genes but shared within a population of individuals across generations over a period of time.

Culture is important to education (curriculum) since it shapes people's thinking, beliefs, actions and the ways they interconnect. It also has an influence on policy, curriculum, pedagogy and assessment (Vass 2017, 452). Ford (2010) allude that the "curriculum is the road map for what will be taught, when it will be taught, and the materials that will be used". The education system in the previously colonised countries was not set up to transmit the culture of the inhabitants of those countries. It was intended to spread the English-speaking's culture. A culturally responsive curriculum is a critical element in reversing this trend.

According to Portland State University (2018), a culturally responsive curriculum (CRC) can be seen as the use of "cultural knowledge, prior experiences, frames of reference and performance styles of ethnically diverse students to make learning encounters more relevant and effective". Culturally responsive teaching is the expression of knowledge, beliefs, and values that recognises the importance of cultural diversity in learning. A CRC pursues to create connections between home and school. Misco $(2018,84)$ further maintains that if students' point of view differs from the western worldview, they are more likely to find themselves in conflict with the curriculum being taught. "The personal and cultural knowledge taught should contain the concepts, explanations and interpretations that students derive from personal experiences in their homes, families, and community cultures" (Montgomery 2001). A CRC incorporates students' racial or ethnic culture, views and experiences into the curriculum in order to advance their academic skills and help them to come up with ways to use their knowledge and skills to improve their lives, communities and society.

The concept culturally responsive has several denotations. Essentially, it means responding proactively and sympathetically to appeals, efforts and influences. When people are responsive, they feel an obligation to address a need so that students experience success. The curriculum is culturally responsive when it is student-centred; it removes barriers to learning and achievement; and opens doors for culturally different students to reach their potential (Ford 2010). To be culturally responsive means that the curriculum and people who deliver it are proactively and emphatically working to comprehend, respect and meet the needs of students coming from dissimilar cultural backgrounds. A culturally responsive curriculum is studentand, by default, culture-centred (Richards, Brown and Forde 2007, 64). A student-centred curriculum cannot exist if culture is ignored. Culture matters in every curriculum (Ford 2010). 


\section{HUMANISING HIGHER EDUCATION BY MAKING CURRICULUM CULTURALLY RESPONSIVE}

The indigenous people of previously colonised countries experience the loss of their identity, culture, humanness, independence and way of life in general. What happened during colonisation was inhuman and the intention now should be to bring back the human character to people who were once belittled. For this reason, higher education curricula require attention. One way in which higher education curricula can be humanised is by making it respond to culture. A curriculum plays an indispensable role in students' lives, not only because it serves as a tool for their learning and growth, but also because it stimulates how they comprehend the world and locate themselves within it.

Mahabeer (2018) submits that the intention of re-humanising education and the curriculum should be to make better human beings for a better society. The humanist approach ensures that curriculum change is locally and contextually relevant. Decolonising the curriculum acknowledges diversity, ethics and language, universalises the curriculum, creates a synergy between the old and the new curriculum, and focuses on rehumanising the curriculum.

The first attempt to make the curriculum culturally responsive was made long ago, after the attainment of independence of the first African country. The next section explores various educational philosophies such as Ujamaa and Ubuntu/Unhu, that attempted to change colonial curricula and make them responsive to human needs.

Julius Nyerere's philosophy (Ujamaa) was one of several attempts to make the curriculum culturally responsive. According to Shava (2016), Ujamaa advocates an education system that is relevant to African contexts. The determination of education is to inculcate the skills and knowledge that enables individuals to perform optimally to benefit the society. This philosophy maintains that the education system inherited by most colonised societies was not meant to teach indigenous people to look to the future. According to Nyerere (1967), the aim of education is to preserve the cultural heritage of the community. Ujamaa is one of the most significant and widely studied theories of education. Policymakers have continued to draw from it for policy formulation (Ibanga 2016: 109). Ujamaa comprises of two dimensions: Education for selfreliance and Education for liberation (Nasongo and Musungu 2009: 111). Self-reliance means depending on one's own powers and resources rather than those of others. According to the dimension of education for liberation, the curriculum has to increase students' physical and mental liberty to advance the control they have over themselves, their own lives and the environment in which they live. Education has to liberate both mind and body (Wa Thiong'o 1986). Mental freedom is the only key to sincere humanity. Physical freedom is of little or no consequence if the mind remains restrained (Major and Mulvihill 2009). 
In addition to Ujamaa, the infusion of the ubuntu philosophy into higher education will make the curriculum responsive to culture. The meaning of ubuntu can be explained in terms of its etymology. West $(2014,48)$ argue that it can be best understood as a "combination of $u b u$-, meaning being or be-ing or becoming, and -ntu representing being taking concrete form, or temporarily having become". It is borrowed from the Nguni group of languages that is cognate with other Bantu languages. It can be translated as humanness or being human in English. It is a communitarian philosophy that emphasises principles such as ubuntu-inspired leadership, peace, discipline, respect, care, empathy/compassion, morality (ethical), honesty, hospitality, sharing, tolerance and harmony (Letseka 2012). Matolino and Kwindingwi (2013, 197) submit that in Africa, a person is a truly human and an acceptable member of a community if he observes principles of ubuntu mentioned above. Ubuntu is the foundation of African communal cultural life. It serves as a unifying factor bringing people together regardless of their background or wealth. The African philosophy of ubuntu highlights the importance unity of humankind. Murtthi $(2009,221)$ emphasises the importance of constantly considering the principles of ubuntu is essential in efforts to resolve human common problems. Previously colonised countries still wrestle with the atrocities that were inflicted on them during those hard times. A curriculum that is based on the principles of ubuntu would assist in making education more responsive to culture. This will bring back the culture that was destroyed by colonisation.

Zimbabwe also adopted an indigenous philosophy (Hunhu) which is close to the philosophy of ubuntu. The Zimbabwean policy of National Reconciliation was based on the Hunhu philosophy. If it is the basis for reconciliation, it is then logical for the curriculum to play a fundamental role in the form of education for reconciliation (Hapanyengwi-Chemhuru and Shizha 2012,24). This philosophy also influenced the Zimbabwean education system. It is a philosophy that sets basis for human relations. Relatedness, according to this view, is central to hunhu. Like ubuntu in South Africa, the philosophy of hunhu is best captured in the saying, kunzi munhu vanhu or umuntu ngumuntu ngabantu, which both expressions can be translated as a person is a person through other persons (Le Grange 2011). West $(2014,48)$ maintains that "to be human is to assert one's humanity by recognising the humanity of others in its infinite variety of content and form". In this sense, ubuntu requires people to have respect for particularity, uniqueness and history, and goes against oppressive belief. Ubuntu emphasises the need for a diversity of views, viewpoints and practices. In other words, people cannot refute the humanity of others without repudiating their own humanity. The individual's identity is a product of social developments within the society. According to Louw (2006), hunhu, like Ubuntu in South Africa, is a unifying idea which serves as a spiritual basis for African societies. It can be argued that hunhu (ubuntu) is the source of African ontology and epistemology. 
To be able to contextualise the curriculum, curriculum developers have to take the Ujamaa, Afrocentric and unhu/ubuntu philosophies into consideration. "Education has to reflect and sustain national priorities, aims and aspirations" (Nasongo and Musungu 2009, 111). From these definitions, it is clear that Nyerere wanted the curriculum to produce educated people who are self-reliant, able to use their own powers, efforts, abilities and resources to promote their own country, and who do not have to rely on outsiders.

\section{RESEARCH DESIGN}

The following research questions were addressed:

- What is the value of a culturally responsive curriculum in humanising higher education?

- To what extent is the current higher education curriculum responsive to culture?

- How can the African philosophies assist in humanising higher education?

A qualitative research approach was appropriate for this study as it enabled an in-depth understanding of participants' views of their life circumstances (McMillan and Schumacher 2014). Data was collected through focus group interviews (FGIs). A 60-minute FGI was conducted at the end of the London International Conference on Education (LICE-2018) and World Congress on Special Needs Education held from 10 to13 December 2018 in Cambridge, UK. A FGI is "a purposive discussion of a specific topic or related topics taking place between eight or ten individuals with a similar background and common interest" (Rabiee 2004). Ten volunteers were selected from presenters whose papers were related to the contextualisation of the curriculum. An e-mail requesting a 60-minute discussion was sent to them. Of the ten presenters, only five agreed to participate.

Data collection was based on an interview guide consisting of several questions. These questions covered what participants considered the main features of an effective Culturally Responsive Curriculum (CRC). Questions used covered topics such as a culturally responsive curriculum to humanise higher education, the status of the current culture responsive curriculum in higher education, and the way in which African philosophies can assist in humanising higher education. The topics were identified after the presenters explained the difficulties they experience in the tutoring of their modules. Questions were validated by a research expert to ensure that they addressed the specific research questions in this chapter.

Initial questions were read out from the interview guide. Follow-up questions were asked depending on the responses given. I moved on to the next question only if the questions on a 
particular issue were sufficiently addressed. Domination by any member of the group was avoided and all presenters were encouraged to participate actively. Responses to questions were varied, although some complemented one another.

\title{
FINDINGS
}

The responses given to the questions centred on the value of a culturally responsive curriculum, the current status of higher education curriculum, and what can be done to make higher education culturally responsive.

\section{The value of a culturally responsive curriculum in humanising higher education.}

The value of a culturally responsive curriculum (CRC) emerged from the literature review. However, participants attached the following meanings to a CRC:

\begin{abstract}
"It 'takes the culture of learners as the centre of classroom activities'; 'identifies the importance of including students' cultural issues in all aspects of learning; the characteristics of a culturally responsive methodology are positive perceptions of parents and families and their way of life; distinctive cultural strengths are identified and cherished to promote learner achievement; provides learners with a sense of well-being about their cultural place in the community; leaners with different cultural and language backgrounds can perform exceptional academically; effective teaching and learning is achieved through a culturally oriented context with a focus on the learner'."
\end{abstract}

All participants demonstrated an understanding of the concept culturally responsive curriculum. They explained it as teaching which takes culture into consideration. A culturally responsive curriculum was considered as teaching that takes culture as its point of departure.

\section{The status of the current culture-responsive curriculum in higher education}

According to literature and the participants, current curricula do not acknowledge culture sufficiently. The following remarks were made by participants:

“... one of the principles of culturally responsive teaching is to be mindful of the social and cultural background of the students. During the preparation of modules, lecturers should have a knowledge of the cultural issues that students bring from home ...; teaching should be inclusive. It can be by upholding the views of students from varied circumstances. Inclusion of all students from various cultures and backgrounds will be one of the essential aspects of culturally responsive teaching."

The views above include important aspects of a culturally responsive curriculum. For example, participants mentioned the inclusion of students' social and cultural background, the knowledge students bring from home, upholding their cultural views, and inclusion of their various cultures. 


\section{The way in which African philosophies can assist in humanising higher education}

Three African participants responded in the following manner to the question of how African philosophies can assist in humanising higher education:

“... Julius Nyerere formulated the philosophy called Ujamaa to decolonise education in Tanzania. According to Ujamaa, the aim of education is to preserve the cultural heritage of the Tanzanian community."

“... Ujamaa is one of the most powerful and most studied philosophies of education ... Ujamaa is education for self-reliance and education for liberation. Self-reliance means depending on one's own powers and resources rather than those of others."

“... Another African philosophy worth mentioning is Hunhu. The Zimbabwean policy of National Reconciliation was based on the philosophy of Hunhu. The curriculum played a fundamental role in education for reconciliation. This philosophy also influenced the Zimbabwean education system."

\section{CONCLUSION (RECOMMENDATIONS)}

The aim of this study was to determine the way in which higher education curricula can be humanised by making it culturally responsive. Philosophies to decolonise education in various African countries were mentioned in literature and by the participants who were interviewed. These philosophies must be taken as the foundation of the current effort to transform education and serve humanity.

The following should be executed to humanise higher education curricula and make them culturally responsive:

- The curriculum must respond to the culture of the people taught. Knowledge transmitters should put the culture of students at the centre of lecture room activities. Colonisation affected indigenous people for many years, and to free them from western ideas is not an easy task. Academics should realise the importance of including students' cultural background in all aspects of learning. Education is not about the educators who deliver the content, but it is all about what students want.

- The methods used in knowledge transmission should respond to the culture of students. For example, talking in circles is characteristic of the way Africans share cultural knowledge. This applies not only to Africans since each nation has its own culture that educational activities must respond to.

- $\quad$ Literature and the participants maintain that current curricula do not respond sufficiently 
to culture. If curricula or education in general were responding to culture, students wouldn't have demanded the decolonisation of the curriculum. Knowledge transmission should be mindful of the social and cultural background of the students.

- Institutions should insist on the inclusion of the cultural knowledge that students have acquired at home and in their communities during the compilation of modules.

- Higher education will be inclusive if the views of students from various circumstances, cultures and backgrounds are recognised.

- Ujamaa as an attempt to decolonise education. Education should lead to self-reliance and the liberation of previously colonised communities. Self-reliance means depending on one's own powers and resources rather than those of others. Academics from previously colonised communities must take the lead in the education system so that education can lead to self-reliance and liberation.

- A policy of national reconciliation (like the one in Zimbabwe based on the philosophy of Hunhu) should be incorporated in education.

\section{REFERENCE}

Anderson, J. 2016. Paulo Freire's philosophy of education and our ontological incompleteness. https://partiallyexaminedlife.com/2016/08/30/paulo-freires-philosophy-of-education-and-ourontological-incompleteness/ (Accessed 13 July 2019).

Ford, D. Y. 2010. Culturally responsive classrooms: Affirming culturally different gifted students. Winter 33(1): 50-53.

Ford, D. Y. and J. L. Moore. 2004. Creating responsive gift understanding of culture is the first step. Fall 27(4): 34-39.

Gadotti, M. 2017. The global impact of Freire's pedagogy. In Pedagogy of evaluation. New directions for evaluation, ed. M. Q. Patton, 155: 17-30.

Gale, T. 2005. Humanization and dehumanization. Encyclopedia of Science, Technology, and Ethics. https://www.encyclopedia.com/science/encyclopedias-almanacs-transcripts-and-maps/ humanization-and-dehumanization (Accessed 13 July 2019).

Galloway, C. M. 2001. Vygotsky's constructionism. In Emerging perspectives on learning, teaching, and technology, ed. M. Orey. http://www.epltt.coe.uga.edu/ (Accessed 28 June 2017).

Hapanyengwi-Chemhuru, O. and E. Shizha. 2012. Unhu/Ubuntu and education for reconciliation in Zimbabwe. Journal of Contemporary Issues in Education 7(2): 16-27. https://ejournals.library. ualberta.ca/index.php/JCIE/.../15158

Hapanyengwi-Chemhuru, O. and N. Makuvaza. 2014. Unhu: In search of an indigenous philosophy for the Zimbabwean education system. Practice without thought is blind: Thought without practice is empty. The Journal of Indigenous Social Development 3(1): 1-15.

Ibanga, F. D. 2016. Julius Nyerere's philosophy of education: Implication for Nigeria's educational system reforms. Africology: The Journal of Pan African Studies 9(3): 109-125.

Kim, B. 2001. Social constructivism. In Emerging perspectives on learning, teaching, and technology, ed. M. Orey. http://projects.coe.uga.edu/epltt/ (Accessed 28 July 2019).

Le Grange L. L. 2011. Sustainability and higher education: From arborescent to rhizomatic thinking. Educational Philosophy and Theory 43(7): 742-754 
Lemmer, E. M. and J. N. van Wyk. 2012. Multicultural education: A manual for the South African teacher. Van Schaik: Pretoria.

Letseka, M. 2012. "In defence of ubuntu". An International Journal Studies in Philosophy and Education 31(1): 47-60. DOI: 10.1007/s11217-011-9267-2.

Louw, D. J. 2006. The African concept of ubuntu and restorative justice. In Handbook of restorative justice: A global perspective, ed. D. Sullivan and L. Tifft, 161-173. New York: Routledge.

Mahabeer, P. 2018. Curriculum decision-makers on decolonising the teacher education curriculum. South African Journal of Education 38(4): 1-13.

Mahmoudi, A., A. Khoshnood and A. Babaei. 2014. Paulo Freire critical pedagogy and its implications in curriculum planning. Journal of Education and Practice 5(14): 87-98.

Major, T. and T. M. Mulvihill. 2009. Julius Nyerere (1922-1999), an African philosopher, re-envisions teacher education to escape colonialism. Journal of Marxism and Interdisciplinary Inquiry 3(1): $15-22$.

Matolino, B. and W. Kwindingwi. 2013. The end of Ubuntu. South African Journal of Philosophy 32(2): 197-205.

McMillan, J. and S. Schumacher. 2014. Research in education evidence-based inquiry. Pearson Education Limited. USA.

Misco, T. 2018. Culturally responsive curriculum and pedagogy in the commonwealth of the Northern Mariana Islands. International Journal of Multicultural Education 20(2): 81-100.

Montgomery, W. 2001. Creating culturally responsive, inclusive classrooms. TEACHING Exceptional Children 33(4): 4-9.

Msila, V. 2009. Ubuntu and peace-making in schools. International Journal of Educational Policies 3(1): 51-66.

Msila, V. and M. T. Gumbo. 2016. Africanising the curriculum: Indigenous perspectives and theories. RSA: Sun Press.

Murtthi, T. 2009. An African perspective on peace education: Ubuntu lessons in reconciliation. International Review of Education 55(-): 221-233.

Nasongo, J. W. and L. L. Musungu. 2009. The implications of Nyerere's theory of education to contemporary education in Kenya. Educational Research and Review 4(4): 111-116.

Ndlovu-Gatsheni, S. J. 2015. Decoloniality in Africa: A continuing Search for a New World Order. ARAS 36(2): 22-50.

Nyerere, J. K. 1967. Education for self-reliance. The Ecumenical Review 19(4): 24-45.

Petrović, Z. S., M. Cvetković and A. Jovanović. 2012. Humanization of school according to the idea of Paulo Freire. Philosophy, Sociology, Psychology and History 11(1): 33-42.

Portland State University. 2018. Culturally responsive and inclusive curriculum resources: What is culturally responsive curriculum? https://guides.library.pdx.edu/c.php?g=527355\&p=3623937 (Accessed on 16 November 2020)

Rabiee, F. 2004. Focus-group interview and data analysis. Proceedings of the Nutrition Society, 63(-): 655-660. DOI:10.1079/PNS2004399.

Richards, H. V., A. F. Brown and T. B. Forde. 2006. Addressing diversity in schools: Culturally responsive pedagogy. Denver: National Center for Culturally Responsive Educational Systems.

Roberts P. 2016. Freire's philosophy and pedagogy: Humanization and education. In Encyclopedia of Educational Philosophy and Theory, ed. M. Peters. Singapore: Springer.

Salazar, M. D. C. 2013. A humanizing pedagogy: Reinventing the principles and practice of education as a journey toward liberation. March, 37(-):121-148. DOI: 10.3102/0091732X12464032.

Shava, S. 2016. The ownership of global knowledge. In Africanising the curriculum: Indigenous perspectives and theories, ed. V. Msila and M. T. Gumbo. South Africa: Sun Press. 
Spencer-Oatey, H. 2012. What is culture? A compilation of quotations. GlobalPAD Core Concepts. GlobalPAD Open House: http://www.warwick.ac.uk/globalpadintercultural

Vass, G. 2017. Preparing for culturally responsive schooling: Initial teacher educators into the fray. Journal of Teacher Education 68(5): 451-462.

Vygotsky, L. S. 1978. Mind in society. Cambridge: Harvard University Press.

Wa Thiong'o, N. 1986. Decolonisation of the mind: The politics of language in African literature. London: Heinemann.

West, A. 2014. Ubuntu and business ethics: Problems, perspectives and prospects. Journal of Business Ethics 121(1): 47-61. 